DOI: 10.5152/cjms.2021.2857

Original Article

\title{
Clinical Decision Making Levels of Nursing Students and Affecting Factors
}

Authors: Burcu Arkan ${ }^{1-0000-0002-7285-6196}$, Dilek Y1lmaz ${ }^{2-0000-0001-7269-8493}$, Hava Gökdere Çinar ${ }^{3-0000-}$ 0002-5792-5958, Rabia Uzun ${ }^{1-0000-0002-0548-648 X}$

\section{Institutions:}

${ }^{1}$ Department of Psychiatric Nursing, Bursa Uludağ University Faculty of Health Sciences, Bursa, Turkey ${ }^{2}$ Department of Fundamentals of Nursing, Bursa Uludağ University Faculty of Health Sciences, Bursa, Turkey

${ }^{3}$ Department of Administration Nursing, Bursa Uludağ University Faculty of Health Sciences, Bursa, Turkey

Corresponding Author: Burcu Arkan

E-mail: arkanburcu@yahoo.com

Received Date: 15.09.2020

Accepted Date: 08.01.2021

Cite this article as: Arkan B, Yllmaz D, Gökdere Çinar H, Uzun R. Clinical Decision

Making Levels of Nursing Students and Affecting Factors. Cyprus J Med Sci 2021; DOI: 10.5152/cjms.2021.2857.

This article has been accepted for publication and undergone full peer review but has not been through the copyediting, typesetting, pagination and proofreading process, which may lead to differences between this version and the Version of Record. Please cite this article as: Arkan B, Yılmaz D, Gökdere Çinar H, Uzun R. Clinical Decision Making Levels of Nursing Students and Affecting Factors. Cyprus J Med Sci 2021; DOI: 10.5152/cjms.2021.2857.- Available online at https://cyprusjmedsci.com/EN 


\begin{abstract}
Background/Aims: Although clinical decision making is an integral part of nursing practice, there are very few studies that investigate the factors affecting decision making. This study was conducted to find out nursing students' levels of clinical decision making and the affecting factors.

Materials and methods: This research was carried out as cross-sectional and descriptive. The research was carried out on 362 1st, 2nd, 3rd and 4th grade students studying at Faculty of Health Sciences Department of Nursing The data of the research were collected by using the "Sociodemographic Data Collection Form" and "The Clinical Decision Making in Nursing Scale. In the analysis of the data, numbers, percentages, means were used with Mann-Whitney U Test and Kruskal Wallis Test.
\end{abstract}

Results: The mean age of the students was $20.75 \pm 1.91$ and $80.9 \%$ of the students were female and $63 \%$ were graduates of anatolian or science high schools. The students' total Clinical Decision Making in Nursing Scale score mean is $100.81 \pm 18.06$. It was found that the variables such as grade, gender, the high school of graduation, number of people living in the family, education and employment status of the parents, choosing the department willingly, the high school of graduation, income and employment status did not affect clinical decision making status of the students $(\mathrm{p}>.05)$.

Conclusion: As a result of the study, it has been found that the students' status of clinical decision making is at medium level. It is recommended to repeat the study on students studying in a different curriculum in nursing, on a larger sample group and to analyze the students' level of clinical decision making in terms of variables such as critical thinking, problem solving and clinical learning environment.

Keywords: nursing, clinical, decision, practice, education

\title{
Main Points
}

This article has been accepted for publication and undergone full peer review but has not been through the copyediting, typesetting, pagination and proofreading process, which may lead to differences between this version and the Version of Record. Please cite this article as: Arkan B, Y1lmaz D, Gökdere Çinar H, Uzun R. Clinical Decision Making Levels of Nursing Students and Affecting Factors. Cyprus J Med Sci 2021; DOI: 10.5152/cjms.2021.2857.- Available online at https://cyprusjmedsci.com/EN 
- Although clinical decision making is an integral part of nursing practice.

- The nursing students' status of clinical decision making is at a medium level.

- It has been found that variables such as grade, gender, high school of graduation, number of members living in the family, education status of parents, attending the department willingly, income and employment status do not affect the clinical decision making status of students.

\section{INTRODUCTION}

Decision making can be defined as selecting the most appropriate possible way to solve a problem. The process of decision making is a mental process that starts with the perception of a situation as a problem by an individual and includes the selection of an activity related to a behavior from one or more options, in order to achieve a desired goal (1).

Clinical decision making is the ability to use the basic and current knowledge of nursing, which includes nonlinear and multi-faceted interactions (2). According to this approach, clinical decision making allows the nurse to observe the patient's condition, evaluate the observed data, critically question their causes, and identify alternative hypotheses. It includes choosing the most possible hypothesis among them and determining and implementing the most correct attempts for the hypothesis chosen $(3,4)$.

Clinical decision making is a basic skill that needs to be developed in all health professionals who offer health care, especially the nurses (5). Clinical decision making, which expresses the ability of the nurses to use and combine their theoretical and practical knowledge, requires the nurse to access new information through different methods during this process (2). In order for the nurse to make the right and effective decision, it is very important to reach the most accurate information for the solution of the existing problem and use it in the process of decision making

This article has been accepted for publication and undergone full peer review but has not been through the copyediting, typesetting, pagination and proofreading process, which may lead to differences between this version and the Version of Record. Please cite this article as: Arkan B, Yılmaz D, Gökdere Çinar H, Uzun R. 
(6). Clinical decision making, which is a complicated process that involves a series of decisions to achieve the targeted results in patient care, is also an essential part of the nursing process $(7,8)$.

Clinical decision making is one of the skills that should be gained to students in nursing education $(9,10,11)$. Therefore, there is a need to determine the clinical decision making perception of nursing students and improve and evaluate their decision making skills during the education process, and there are currently limited number of studies on perceptions of nursing students and understandings of clinical decision making $(11,12)$. As decision making is a complex process and many factors affect this process, it is difficult to study clinical decision making on nursing students $(9,11)$. In the study of Garrett (11) (2005), it was found that nursing senior students perceive clinical decision making as a complex conceptual process and at the same time think that clinical decision making is related to knowledge and experience. In the literature, it has been suggested that there have been changes in critical thinking and intellectual development with undergraduate nursing education, however, these changes will take several years and should be applied in clinical decision making processes $(11,12,13)$. In their qualitative study, Jahanpour et al. (14). (2010) reported that insufficient number of clinical instructors, low self-sufficiency, unsuitable clinical learning environment and stress negatively affect decision making in students and students cannot decide independently. In the study conducted by Ho et al. (2013) (15) on senior students at the nursing school in Malaysia, it was reported that the students' Clinical Decision Making in Nursing Scale (CDMNS) score means were good, and that this result was affected by the facts that nursing was their first preference and they are satisfied of being a nurse. In the study in which the clinical decision making perception of nursing students were analyzed in our country (13), it was found that there was a difference between grades in clinical decision making levels of the students, and as a result of one year of follow-up, it was found that the clinical decision making scores of the senior students were lower. In a study conducted by Özden et al. (2018) (16) to find the clinical decision making levels of nursing students and the factors affecting them, the students' status of clinical decision making was reported to be affected by variables such as the employment status

This article has been accepted for publication and undergone full peer review but has not been through the copyediting, typesetting, pagination and proofreading process, which may lead to differences between this version and the Version of Record. Please cite this article as: Arkan B, Y1lmaz D, Gökdere Çinar H, Uzun R. Clinical Decision Making Levels of Nursing Students and Affecting Factors. Cyprus J Med Sci 2021; DOI: 10.5152/cjms.2021.2857.- Available online at https://cyprusjmedsci.com/EN 
of the mother, entering the department willingly, liking nursing as a profession, having a positive opinion about the profession, not having problems in clinical practice and thinking that they use the theoretical knowledge in clinical practice.

Although there are studies on the clinical decision making levels of the students in the literature, it has been observed that there are limited number of studies that reveal the factors that affect the clinical decision making level of the students. It is thought that the findings obtained through this study can assist the instructors in improving clinical decision making in nursing students and in identifying the appropriate educational and clinical strategies. This research was carried out to find out the clinical decision-making levels of nursing students and the effecting factors The study seeks an answer to the question "what are the factors affecting the clinical decision-making skills of nursing students?”.

\section{MATERIALS AND METHODS}

\section{Design and sample}

The research was conducted in Bursa Uludağ University Faculty of Health Sciences Department of Nursing between March and April 2019, in descriptive and cross-sectional type.

The universe of the research consisted of 771 st, $2 \mathrm{nd}, 3 \mathrm{rd}$ and 4 th grade students who were studying in the nursing department of a university's faculty of health sciences during the 20182019 academic year. The sample of the study comprised 362 students, who agreed to take part in the study and completed the study forms after necessary explanations about the study were made, without using any sampling methods on the students comprising the target population.

The dependent variable of the study was clinical decision-making skills of students, while the independent variables were grade, age, gender, number of siblings, number of family members, type of high school graduated, status of choosing the department willingly, income status,

This article has been accepted for publication and undergone full peer review but has not been through the copyediting, typesetting, pagination and proofreading process, which may lead to differences between this version and the Version of Record. Please cite this article as: Arkan B, Yılmaz D, Gökdere Çinar H, Uzun R. 
accommodation, employment, educational background of parents and place lived longest, which were available in the sociodemographic data form.

\section{Data Collection Tools}

The data of the study were collected by using the "Socio-Demographic Data Collection Form" and "The Clinical Decision Making in Nursing Scale (CDMNS-Tr)".

Socio-Demographic Data Collection Form: This form was developed by the researchers and consists of 9 closed-ended questions that include the grade, age, gender, school of graduation of the students, whether they chose the department willingly or not, where they live, their employment status, the education and employment status of their parents.

The Clinical Decision Making in Nursing Scale (CDMNS): Developed by Jenkins (1983) on nursing students in the USA, this scale describes the clinical decision making perception of nursing students based on self-expressions (17). The cronbach alpha reliability coefficient of the scale was found to be 0.83 (18). The cronbach alpha reliability coefficient of the clinical decision making in nursing scale, which has been adapted into Turkish by Durmaz and Sarikaya (19), is 0.78. In this study, the cronbach alpha reliability coefficient has been calculated as 0.81 .

The original CDMNS consists of 40 items and four subscales. The subscales of the scale are as follows respectively; "search for alternatives or options", "canvasing of objectives and values", "Evaluation and reevaluation of consequences", and "Search for information and unbiased assimilation of new information". Each subscale is composed of 10 items. 22 items $(1,3,5,7,8$, $9,10,11,14,16,17,18,20,26,27,28,29,33,35,36,37,38)$ are positively and 18 items $(2,4,6$, $12,13,15,19,21,22,23,24,25,30,31,32,34,39,40)$ are negatively significant. The 18 negatively significant items of the scale are inversely scored. Each item of the scale is evaluated as 5=Always, 4=Frequently, 3=Occasionally, 2=Seldom, 1 = Never.

This article has been accepted for publication and undergone full peer review but has not been through the copyediting, typesetting, pagination and proofreading process, which may lead to differences between this version and the Version of Record. Please cite this article as: Arkan B, Y1lmaz D, Gökdere Çinar H, Uzun R. 
The minimum and maximum points to be taken are 40 and 200 in the whole scale and 10 and 50 in each subscale. A high score taken from the scale indicates that the perception in decision making is high and a low score indicates that the perception in decision making is low. The scale is evaluated considering each subscale and the total score of the scale $(17,18,19)$.

\section{Data Collection}

These questionnaire forms were applied outside the course and clinical practice periods. Before the questionnaire forms were applied, the participants were informed by explaining the objective of the research. The questionnaire forms, which were distributed on a voluntary basis, were filled under the supervision of the researcher. It took them about 20 minutes to complete the questionnaire forms.

For the implementation of the research, written permissions from the Faculty in which the research was conducted and from the university ethics committee (Decision no: 2019/03) and verbal informed consents from the students were obtained.

The data obtained from the research were analyzed by using SPSS 22.0 (Statistical Package for Social Science) statistical program software. In the analysis of the data; numbers, percentages, means, mann-whitney $\mathrm{u}$ test, kruskal wallis test were used. The $\mathrm{p}$ value which is under 0.05 was accepted statistically significant.

\section{RESULTS}

The mean age of the students participated in the study was $20.75 \pm 1.91$ and $80.9 \%$ of them were female. $25,1 \%$ of the students were 1 st grade, 27,6\% were 2 nd grade, 21,5\% were 3rd grade, and $25,7 \%$ were 4 th grade students. $63 \%$ of the students were graduates of anatolian-science high schools. $71,5 \%$ of the students did not come to the department willingly. The mothers of the $4,0 \%$ of the students and the fathers of the $18.0 \%$ of the students were university graduates.

This article has been accepted for publication and undergone full peer review but has not been through the copyediting, typesetting, pagination and proofreading process, which may lead to differences between this version and the Version of Record. Please cite this article as: Arkan B, Yılmaz D, Gökdere Çinar H, Uzun R. 
Students' Clinical Decision Making in Nursing Scale (CDMNS-Tr) score mean is $100.81 \pm$ 18.69. When the sub-dimension Clinical Decision Making in Nursing Scale score mean of the students is analyzed; "Search for Alternatives or Options" was $25.52 \pm 5.38$, "Canvasing of Objectives and Values" was $22.95 \pm 5.19$, "Evaluation and Reevaluation of Consequences" was $26.54 \pm 5.61$, "Search for Information and Unbiased Assimilation of New Information" was 25.59 \pm 5.15 (Table 1).

Table 2 shows the distribution of the students' Clinical Decision Making in Nursing Scale (CDMNS-Tr) and subscale score means. The CDMNS-Tr score means of the 1st, 2nd, 3rd and 4th grade nursing students are respectively; $100.98 \pm 18.82,100.37 \pm 20.00,102.61 \pm 14.88,99.60 \pm$ 20.11. It was determined that the total CDMNS-Tr score means were similar among all the students and the difference was not statistically significant $(\mathrm{p}=.082)$. It was found that the students' CDMNS-Tr sub-dimension score means did not show an important statistically significant difference $(\mathrm{p}=.091)($ Table 2$)$.

In Table 3, distribution of The Clinical Decision Making in Nursing Scale score means is shown according to some characteristics of nursing students. It has been found that male students (110.10) have a higher score mean in CDMNS-Tr, compared to female students (100.97), but the difference is not statistically significant ( $p>0.05)$. The students were examined in terms of the variables of the high school they graduated, their coming to the department willingly or not, their employment status, place of residence and income status, and their CDMNS-Tr score means have not been found statistically significant $(\mathrm{p}>0.05)$.

\section{DISCUSSION}

Technological developments have also provided the development of nursing and strengthened its roles and functions. While problem solving in nursing has mostly been done through trial and error, decision making has gained an information-based infrastructure in the light of scientific approaches developed today $(20,21)$. Clinical decision making, which expresses the ability of the

This article has been accepted for publication and undergone full peer review but has not been through the copyediting, typesetting, pagination and proofreading process, which may lead to differences between this version and the Version of Record. Please cite this article as: Arkan B, Yılmaz D, Gökdere Çinar H, Uzun R. Clinical Decision Making Levels of Nursing Students and Affecting Factors. Cyprus J Med Sci 2021; DOI: 10.5152/cjms.2021.2857.- Available online at https://cyprusjmedsci.com/EN 
nurses to use and combine their theoretical and practical knowledge, required the nurse to access new information through different methods in this process. In order for the nurse to make the right and effective decision, it is very important to reach the most accurate information for the solution of the existing problem and use it in the decision making process $(6,22)$. In addition to that, the ability of clinical decision making in nursing is one of the most important skills that nursing students should learn and use in nursing practices in order to ensure patient safety and provide the most appropriate care service (15). Based on this direction, in this study, it was aimed to reveal the clinical decision making levels of the nursing department students who are candidates of nursing profession and the effecting factors. As a result of the study, the students' Clinical Decision Making in Nursing Scale (CDMNS-Tr) score mean has been found to be $100.81 \pm 18.69$. Considering that the highest score that can be obtained from the scale is 200 , it is possible to say that the students' clinical decision making levels are medium. Considering the national and international studies on the subject; clinical decision making levels of students have been found high $(13,15,16,22,23)$. The result of our study is not similar to these study findings. This difference between studies may have resulted from the fact that the studies were carried out in schools where different course curricula and educational methods were applied.

Nursing students must also be able to keep the process of fast and accurate clinical decision making in changing conditions by interpreting different information $(16,24)$. They found that the clinical decision making perception of nursing students was at medium levels in the subdimensions of "search for alternatives or options", "canvasing of objectives and values", "Evaluation and Reevaluation of Consequences" and "Search for Information and Unbiased Assimilation of New Information". When the literature is reviewed, in the studies of Özen et al. (2017) (22), the sub-dimensions of the CDMNS-Tr of the students have been observed to be above average, and in the studies of Özden et al. (2018) (16), they have been observed to be high. With this aspect, our research results are not similar to the literature.

This article has been accepted for publication and undergone full peer review but has not been through the copyediting, typesetting, pagination and proofreading process, which may lead to differences between this version and the Version of Record. Please cite this article as: Arkan B, Y1lmaz D, Gökdere Çinar H, Uzun R. 
In a study they conducted on nurses, Chen et al. (2016) (25) emphasized that clinical experience affects clinical decision making. As a result of our study, it has been observed that the grade levels at which the students study, do not affect their clinical decision making levels. Although there is no significant difference between them, the highest CDMNS-Tr score mean has been found in 3rd grade students and the lowest score mean has been found in 4th grade students. In the literature, it is reported that the clinical decision making skills of students increase with clinical experience, at all stages of education $(13,26)$. However, in our study, the clinical decision making levels of the senior students have been observed to be lower than the students studying in the lower grades. When the literature is reviewed, it has been observed that simulations of practices have a positive effect on the clinical decision making levels of nursing students $(27,28)$. The fact that the clinical skills of the students, who participated in the research, are supported by simulation only in the first grade and the lack of simulation-based practices in the higher grades may have caused the fourth-year students to have the lowest clinical decision making skills. On the other hand, in the fourth grade internship practice, students take on the responsibility almost identical to a nurse and need a lot of information to learn. In addition to that, nurses working in the clinic use "Computer Based Decision Support Systems" (29). Within the education curriculum, these systems are mentioned only theoretically and the students do not practice on these systems. This may have caused them to feel insufficient in the clinical decision making process. Moreover, similar to our study topic, as a result of the study conducted to reveal the clinical decision making levels of nursing students and the variables that affect them, by Özden et al. (2018) (15); it was found that the variable of grade did not affect the clinical decision making levels of the students. Aktaş and Karabulut (30) and Özen et al. (2017) (22) found similar results in their studies. The result of our study is observed to support the findings of these studies.

In the research, it has been concluded that the gender factor of the students do not affect their clinical decision making levels. Similar results were also found in the study conducted by Özden et al. (2018) (16). Unlike this study, some studies have stated that gender is directly related to the copyediting, typesetting, pagination and proofreading process, which may lead to differences between this version and the Version of Record. Please cite this article as: Arkan B, Y1lmaz D, Gökdere Çinar H, Uzun R. 
decision making process $(3,31)$. Our study result does not support these study results. This made us think that this difference may be due to the fact that the majority of the students who participated in our study were female, and that a balanced ratio could not be established in the study sample group. On the other hand, as a result of the study, it has been found that the high school type and income status of the students do not affect their clinical decision making levels. Exactly similar to this issue, the result of the study that analyzes the effect of these two variables on the clinical decision making levels of the students could not be reached, and it is possible to conclude from these results that the high school type and income status of the students do not have a significant effect on the clinical decision making levels.

It is thought that providing a democratic environment in the family, which is the closest environment where individuals grow, can change the factors that may affect students' decision making skills such as self-expression and taking responsibility (32). For this purpose, when the education levels of their parents and their status of choosing this department willingly were questioned, no significant difference was found between these variables and the CDMNS-Tr score mean. Özden et al. (2018) (16) found in their research that, individual differences such as the employment status of the mothers of the students and their attending the department willingly, affected their clinical decision making levels. The difference with the literature may have resulted from the fact that very few of the students in the sample group had working mothers, and therefore a homogeneous distribution could not be provided in this regard.

\section{CONCLUSIONS}

Clinical decision making, which involves a series of decisions in order to carry out the patient care process effectively and is a complicated process, is a basic skill that should be developed during the education process of nursing students. As a result of this study, it has been revealed that the nursing students' status of clinical decision making is at a medium level. It has been found that variables such as grade, gender, high school of graduation, number of members living in the

This article has been accepted for publication and undergone full peer review but has not been through the copyediting, typesetting, pagination and proofreading process, which may lead to differences between this version and the Version of Record. Please cite this article as: Arkan B, Yılmaz D, Gökdere Çinar H, Uzun R. 
family, education status of parents, attending the department willingly, income and employment status do not affect the clinical decision making status of students.

Nurse educators and administrators have great responsibilities in improving nursing students' skills of decision making. In this context;

$>\quad$ Repeating the study on a larger sample group, on students studying in different curriculum in nursing,

$>\quad$ Investigating the clinical decision making levels of students in terms of the variables such as critical thinking, problem solving, clinical learning environment, also considering the individual differences and communication skills,

$>$ Improving the current conditions of the realistic patient simulations training that will contribute to the clinical decision making process of the students in the first grades and also adding them to the curricula of the second, third and fourth grade students,

$>\quad$ In addition to the theoretical knowledge about computer-based decision support systems, implementing training methods that are based on practice and gaining the computer using skills to the student nurses at a more professional dimension during their nursing education, are recommended.

Ethics Committee Approval: Ethics committee approval was received for this study from the ethics committee of the Bursa Uludag University’s Ethics Commitie (Decision no: 2019/03).

Source of Funding: None

Informed Consent: Informed consent was obtained from the nursing students who participated in this study.

Author contributions: Concept - B.A., D.Y., H.G.Ç., R.U.; Design- B.A., D.Y., H.G.Ç., R.U.; Supervision - B.A.; Resource - B.A., D.Y., H.G.Ç., R.U.; Materials - B.A., D.Y., H.G.Ç., This article has been accepted for publication and undergone full peer review but has not been through the copyediting, typesetting, pagination and proofreading process, which may lead to differences between this version and the Version of Record. Please cite this article as: Arkan B, Y1lmaz D, Gökdere Çinar H, Uzun R. Clinical Decision Making Levels of Nursing Students and Affecting Factors. Cyprus J Med Sci 2021; DOI: 
R.U.; Data Collection and/or Processing - B.A., R.U.; Analysis and/or Interpretation - B.A., D.Y., H.G.Ç.; Literature Search - B.A., D.Y., H.G.Ç., R.U.; Writing - B.A., D.Y., H.G.Ç., R.U.; Critical Reviews B.A., D.Y., H.G.Ç.

Acknowledgments: We would like to thank the students who participated in this study.

Conflict of Interest: The authors declare that they have no competing interests.

\section{$\underline{\text { References }}$}

1. Sucu G, Dicle A, Saka O. Hemşirelikte Klinik Karar Verme, Etkileyen Etmenler Ve Karar Verme Modelleri. Hemşirelikte Eğitim ve Araştırma Dergisi 2012;9(1):52-60.

2. Thompson CA. Conceptual treadmill: The need for 'middle ground' in clinical decision making theory in nursing. Journal of Advanced Nursing 1999;30(5):1222-1229.

3. Lauri S, Salanterä S, Chalmers K, et al. An exploratory study of clinical decision-making in five countries. Journal of Nursing Scholarship 2001;33(1):83-90.

4. Inangil D, Uzen Cura S. Nursing Students' Perceptions of Nursing Diagnoses and Clinical Decision-Making. Clin Exp Health Sci 2020;10:131-136. DOI: 10.33808/clinexphealthsci.568335

5. Tanner CA. Thinking like a nurse: a research-based model of clinical judgement in nursing. J Nurs Educ. 2006;45(6):204-211.

6. Junnola T, Eriksson E, Salanterä S, Lauri S. Nurses' decision-making incollecting information for the assessment of patients' nursing problems. J Clin Nurs. 2002; 11(2):186-196.

7. ONeill ES, Dluhy NM, Chin E. Modelling novice clinical reasoning fora computerized decision support system. J Adv Nurs. 2005;49(1):68-77. doi.org/10.1111/j.13652648.2004.03265.x

8. Günerigök F, Yılmaz Kurt F, Küçükoğlu S. Hemşirelik öğrencilerinin klinik karar verme sürecinde özgüven ve anksiyete düzeylerinin belirlenmesi: İki farklı program örneği. Anadolu Hemşirelik ve Sağlık Bilimleri Dergisi 2020;23(1):77-94. DOI: 10.17049/ataunihem.549320

This article has been accepted for publication and undergone full peer review but has not been through the copyediting, typesetting, pagination and proofreading process, which may lead to differences between this version and the Version of Record. Please cite this article as: Arkan B, Yılmaz D, Gökdere Çinar H, Uzun R. Clinical Decision Making Levels of Nursing Students and Affecting Factors. Cyprus J Med Sci 2021; DOI: 10.5152/cjms.2021.2857.- Available online at https://cyprusjmedsci.com/EN 
9. Canova C, Brogiato G, Roveron G, \& Zanotti R. Changes in decision-making among Italian nurses and nursing students over the last 15 years. Journal of Clinical Nursing 2016;25:811818.

10. Durmaz A. Hemşirelik öğrencilerinin ameliyat öncesi ve sonrası hasta bakım yönetimini öğrenmesinde bilgisayar destekli simülasyon tekniğinin etkisi. Hemşirelik Programı Yayınlanmamış Doktora Tezi, Dokuz Eylül Üniversitesi Sağlık Bilimleri Enstitüsü. İzmir, 2012.

11. Garrett B. Student nurses' perceptions of clinical decision-making in the final year of adult nursing studies. Nurse Education in Practice 2005;5:30-39.

12. Botti M, \& Reeve R. Role of knowledge and ability in student nurses' clinical decision-making. Nursing and Health Sciences 2003;5:39-49.

13. Dicle A, Edeer AD. Examination of clinical decision making perceptions of nursing students. The New Educational Review 2013;33(3):134-144.

14. Jahanpour F, Sharif F, Salsali M, Kaveh MH, \& Williams LM. Clinical decision-making in senior nursing students in Iran. International Journal of Nursing Practice 2010;16: 595-602.

15. Ho SE, Koo YL, Ismail S, Hing HL, Widad O, Chung HT et al. Clinical decision making ability of nursing students in a tertiary hospital. Medicine \& Health 2013;8(2):73-80.

16. Özden D, Özveren H, Gülnar E. Hemşirelik Öğrencilerinin Klinik Karar Verme Düzeyleri ve Etkileyen Faktörler. DEUHFED 2018;11(1):41-47.

17. Jenkins HM. Cinical decision making in nursing scale. In: Waltz CF, Jenkins LS, (Ed.), Measurement of Nursing Outcomes volume:1 measuring nursing performance in practice, education and research. (pp. 33-37). USA: Springer Publishing Company. 2001.

18. Jenkins $H$. Perceptions of decision making among baccalaureate nursing students as measured by the clinical decision making in nursing scale, doctors theses, University of Maryland. 1983 USA.

This article has been accepted for publication and undergone full peer review but has not been through the copyediting, typesetting, pagination and proofreading process, which may lead to differences between this version and the Version of Record. Please cite this article as: Arkan B, Yılmaz D, Gökdere Çinar H, Uzun R. Clinical Decision Making Levels of Nursing Students and Affecting Factors. Cyprus J Med Sci 2021; DOI: 10.5152/cjms.2021.2857.- Available online at https://cyprusjmedsci.com/EN 
19. Edeer DA, Sarıkaya A. Adaptation of Clinical Decision Making in Nursing Scale to Undergraduate Students of Nursing: The Study of Reliability and Validity. International Journal of Psychology and Educational Studies 2015;2(3):1-9.

20. Azak A, Taşcı S. Klinik karar verme ve hemşirelik. Türkiye Klinikleri J Med Ethics 2009;17(3):176-83.

21. Taşçı S. Hemşirelikte Problem Çözme Süreci. Sağlık Bilimleri Dergisi Hemşirelik Özel Sayısı 2005; 14:73-78.

22. Özen N, Yazıcıŏlu İ, Çınar Fİ. Hemşirelik öğrencilerinin sağlık bakımında bilgisayar kullanımına yönelik tutumları ile klinik karar verme becerileri arasındaki ilişkinin incelenmesi. Hemşirelikte Eğitim ve Araştırma Dergisi 2017;14(2):112-118.

23. Krumwiede AK. An examination of accelerated and basic baccalaureate nursing students' perceptions of clinical decision making. Capella University, Doctor of Philosophy, 2010, UMI Number: 3409185. Available at https://eric.ed.gov/?id=ED518161. Accessed on; 13 April 2020.

24. Johansen ML, \& O’Brien, JL. Decision making in nursing practice: a concept analysis. Nursing Forum 2016;51(1):40-48.

25. Chen SL, Hsu HY, Chang CF, Lin ECL. An exploration of the correlates of nurse practitioners' clinical decision-making abilities. Journal of Clinical Nursing 2016;25:1016-1024.

26. Atasoy I, Sütütemiz N. Bir grup hemşirelik son sınıf öğrencisinin hemşirelik eğitimi ile ilgili görüşleri. Florence Nightingale Hemşirelik Dergisi, 2014;22(2):94-104.

27. Bonnetain E, Boucheix JM, Hamet M, Freysz M. Benefits of computer screen based simulation in learning cardiac arrest procedures. Medical Education, 2010;44:716-722.

28. Salyers VL. Teaching psychomotor skills to beginning nursing students using a web- enhanced approach: A quasi-experimental study. International Journal of Nursing Education Scholarship 2007;4(1): article 11.

This article has been accepted for publication and undergone full peer review but has not been through the copyediting, typesetting, pagination and proofreading process, which may lead to differences between this version and the Version of Record. Please cite this article as: Arkan B, Yılmaz D, Gökdere Çinar H, Uzun R. Clinical Decision Making Levels of Nursing Students and Affecting Factors. Cyprus J Med Sci 2021; DOI: 10.5152/cjms.2021.2857.- Available online at https://cyprusjmedsci.com/EN 
29. Randell R, Mitchell N, Dowding D et al. Effects of computerized decision support systems on nursing performance and patient outcomes: A systematic review. Journal of Health Services Research \& Policy 2007;12(4):242-249.

30. Aktaş YY, Karabulut N. A Survey on Turkish nursing students' perception of clinical learning environment and its association with academic motivation and clinical decision making. Nurse Education Today 2016;36:124-128.

31. Bjørk IT, Hamilton GA. Clinical decision making of nurses working in hospital setting. Nursing Research and Practice, 2011;8:1-8.

32. Eldeleklioğlu J. Karar stratejileri ile ana-baba tutumları arasındaki ilişki. Türk Psikolojik Danışma ve Rehberlik Dergisi II 1997;11:7-13.

Table 1: Results of the Clinical Decision Making in Nursing Scale and Subscale Analysis (n = 362)

\begin{tabular}{|c|c|c|c|c|}
\hline & $\mathrm{X} \pm \mathrm{SS}$ & Min. & Max. & Range \\
\hline $\begin{array}{l}\text { The total of } \\
\text { CDMNS }\end{array}$ & $100.81 \pm 18.69$ & 40.00 & 141.00 & 101.00 \\
\hline \multicolumn{5}{|c|}{ CDMNS and subscales } \\
\hline $\begin{array}{l}\text { Search for } \\
\text { alternatives or } \\
\text { options }\end{array}$ & $25.52 \pm 5.38$ & 10.00 & 43.00 & 33.00 \\
\hline $\begin{array}{l}\text { Canvassing of } \\
\text { objectives and } \\
\text { value }\end{array}$ & $22.95 \pm 5.19$ & 10.00 & 41.00 & 31.00 \\
\hline $\begin{array}{l}\text { Evaluation and } \\
\text { reevaluation of } \\
\text { consequences }\end{array}$ & $26.54 \pm 5.61$ & 10.00 & 38.00 & 28.00 \\
\hline $\begin{array}{l}\text { Search for } \\
\text { information and } \\
\text { unbiased } \\
\text { assimilation of } \\
\text { new information }\end{array}$ & $25.59 \pm 5.15$ & 10.00 & 40.00 & 30.00 \\
\hline
\end{tabular}

Table 2. Comparison of the scores of students on the Clinical Decision Making in Nursing Scale according to year $(n=362)$

\begin{tabular}{|l|c|c|c|c|}
\hline $\begin{array}{l}\text { CDMNS and } \\
\text { subscales }\end{array}$ & $\mathbf{1}^{\text {st }}$ year (91) & $\mathbf{2}^{\text {nd }}$ year (100) & $3^{\text {rd }}$ year (78) & $4^{\text {th }}$ year (93) \\
\hline & $\mathbf{X} \pm \mathrm{SS}$ & $\mathbf{X} \pm \mathrm{SS}$ & $\mathrm{X} \pm \mathrm{SS}$ & $\mathrm{X} \pm \mathrm{SS}$ \\
\hline
\end{tabular}

This article has been accepted for publication and undergone full peer review but has not been through the copyediting, typesetting, pagination and proofreading process, which may lead to differences between this version and the Version of Record. Please cite this article as: Arkan B, Yılmaz D, Gökdere Çinar H, Uzun R. Clinical Decision Making Levels of Nursing Students and Affecting Factors. Cyprus J Med Sci 2021; DOI: 


\begin{tabular}{|l|l|l|l|l|}
\hline $\begin{array}{l}\text { Search for } \\
\text { alternatives or } \\
\text { options }\end{array}$ & $25,69 \pm 5.48$ & $25.48 \pm 5.71$ & $26.24 \pm 4.66$ & $25.52 \pm 5.38$ \\
\hline $\begin{array}{l}\text { Canvassing of } \\
\text { objectives and } \\
\text { value }\end{array}$ & $23.19 \pm 5.87$ & $22.71 \pm 5.56$ & $22.87 \pm 4.27$ & $23.04 \pm 4.84$ \\
\hline $\begin{array}{l}\text { Evaluation and } \\
\text { reevaluation of } \\
\text { consequences }\end{array}$ & $26.43 \pm 5.55$ & $26.39 \pm 5.91$ & $27.10 \pm 4.63$ & $26.35 \pm 6.13$ \\
\hline $\begin{array}{l}\text { Search for } \\
\text { information and } \\
\text { unbiased } \\
\text { assimilation of new } \\
\text { information }\end{array}$ & $25.39 \pm 5.06$ & $25.60 \pm 5.74$ & $26.20 \pm 3.94$ & $25.29 \pm 5.50$ \\
\hline $\begin{array}{l}\text { The total of } \\
\text { CDMNS }\end{array}$ & $100.98 \pm 18.82$ & $100.37 \pm 20.00$ & $102.61 \pm 14.88$ & $99.60 \pm 20.11$ \\
\hline
\end{tabular}

Table 3. Comparison of the scores of students on the Clinical Decision Making in Nursing Scale according to various features $(n=362)$

\begin{tabular}{|c|c|c|c|c|}
\hline \multirow{2}{*}{$\begin{array}{l}\text { CDMNS and } \\
\text { subscales }\end{array}$} & \multirow[t]{2}{*}{$\mathbf{N}$} & \multirow[t]{2}{*}{ CDMNS } & \multicolumn{2}{|c|}{ Statistical evaluation } \\
\hline & & & $7 / \mathrm{Z} / \mathrm{t}$ & $\mathrm{P}$ \\
\hline \multicolumn{3}{|l|}{ Gender } & \multirow[t]{3}{*}{ Z:.-068 } & \multirow[t]{3}{*}{.946} \\
\hline Male & 69 & 110.10 & & \\
\hline Female & 293 & 100.97 & & \\
\hline \multicolumn{3}{|c|}{ Educational status } & \multirow[t]{3}{*}{ K-W:2.738 } & \multirow[t]{3}{*}{.066} \\
\hline High school & 64 & 103.20 & & \\
\hline $\begin{array}{l}\text { Vocational high } \\
\text { school }\end{array}$ & 70 & 96.31 & & \\
\hline
\end{tabular}

This article has been accepted for publication and undergone full peer review but has not been through the copyediting, typesetting, pagination and proofreading process, which may lead to differences between this version and the Version of Record. Please cite this article as: Arkan B, Yılmaz D, Gökdere Çinar H, Uzun R. Clinical Decision Making Levels of Nursing Students and Affecting Factors. Cyprus J Med Sci 2021; DOI: 


\begin{tabular}{|c|c|c|c|c|}
\hline $\begin{array}{l}\text { Anatolian-science } \\
\text { high school }\end{array}$ & 228 & 101.52 & & \\
\hline \multicolumn{3}{|c|}{ Voluntarily choosing a department } & \multirow[t]{3}{*}{ Z: .261 } & \multirow[t]{3}{*}{.804} \\
\hline Yes & 266 & 100.96 & & \\
\hline No & 96 & 100.38 & & \\
\hline Working status & & & \multirow[t]{4}{*}{ K-W: .983 } & \multirow[t]{4}{*}{.375} \\
\hline Working & 23 & 95.52 & & \\
\hline Not working & 318 & 101.16 & & \\
\hline Part time working & 21 & 101.23 & & \\
\hline \multicolumn{3}{|c|}{ Educational status of your mother } & \multirow[t]{6}{*}{ K-W: .977 } & \multirow[t]{6}{*}{.420} \\
\hline Illiterate & 33 & 103.78 & & \\
\hline Elementary school & 170 & 101.12 & & \\
\hline Secondary school & 67 & 102.64 & & \\
\hline High school & 77 & 97.66 & & \\
\hline University & 15 & 98.66 & & \\
\hline \multicolumn{3}{|c|}{ Educational status of your father } & \multirow[t]{6}{*}{ K-W: 1.056} & \multirow[t]{6}{*}{.378} \\
\hline Illiterate & 8 & 97.12 & & \\
\hline Elementary school & 105 & 101.69 & & \\
\hline Secondary school & 63 & 103.74 & & \\
\hline High school & 119 & 100.59 & & \\
\hline University & 67 & 97.49 & & \\
\hline \multicolumn{3}{|c|}{ Parental employment status } & $\mathrm{K}-\mathrm{W}: 1.435$ & .232 \\
\hline
\end{tabular}

This article has been accepted for publication and undergone full peer review but has not been through the copyediting, typesetting, pagination and proofreading process, which may lead to differences between this version and the Version of Record. Please cite this article as: Arkan B, Yılmaz D, Gökdere Çinar H, Uzun R. Clinical Decision Making Levels of Nursing Students and Affecting Factors. Cyprus J Med Sci 2021; DOI: 10.5152/cjms.2021.2857.- Available online at https://cyprusjmedsci.com/EN 


\begin{tabular}{|c|c|c|c|c|}
\hline Only father works & 257 & 100.42 & & \\
\hline Only mother works & 25 & 107.36 & & \\
\hline Both parents work & 69 & 99.20 & & \\
\hline \multicolumn{3}{|l|}{ Income status } & \multirow[t]{4}{*}{ K-W:1.515 } & \multirow[t]{4}{*}{.221} \\
\hline Low & 16 & 102.62 & & \\
\hline Medium & 290 & 101.47 & & \\
\hline Good & 56 & 96.85 & & \\
\hline \multicolumn{3}{|l|}{ Currently living status } & \multirow[t]{5}{*}{ K-W: .945 } & \multirow[t]{5}{*}{.419} \\
\hline At home with family & 135 & 99.48 & & \\
\hline At home with friends & 64 & 99.00 & & \\
\hline State dormitory & 104 & 102.47 & & \\
\hline Private dormitory & 59 & 102.89 & & \\
\hline
\end{tabular}

This article has been accepted for publication and undergone full peer review but has not been through the copyediting, typesetting, pagination and proofreading process, which may lead to differences between this version and the Version of Record. Please cite this article as: Arkan B, Yılmaz D, Gökdere Çinar H, Uzun R. Clinical Decision Making Levels of Nursing Students and Affecting Factors. Cyprus J Med Sci 2021; DOI: 10.5152/cjms.2021.2857.- Available online at https://cyprusjmedsci.com/EN 